\title{
Factor Structure of the Inventory of Adult Temperament Styles
}

\author{
Estrutura Fatorial do Inventário de Estilos de Temperamento de Adultos
}

\author{
Solange Muglia Wechsler ${ }^{*}, a$, Nicholas Benson ${ }^{b}$, Thomas Oakland ${ }^{c}$ \\ \& Maria Angela Lourençoni ${ }^{d}$ \\ ${ }^{a}$ Pontificia Universidade Católica de Campinas, Campinas, SP, Brasil, \\ ${ }^{b}$ University of South Dakota, Vermillion, Dakota do Sul, USA, ${ }^{c}$ University of Florida, Gainesville, FL, USA \\ $\&{ }^{d}$ Universidade Paulista de Sorocaba, Sorocaba, SP, Brasil
}

\begin{abstract}
Temperament refers to stylistic and relatively stable traits that subsume intrinsic tendencies to act and react in somewhat predictable ways to people, events, and stimuli. Temperament can be defined by four bipolar styles: extroversion-introversion, practical-imaginative, thinking-feeling, and organizedflexible. These four styles provide the theoretical structure for the group administered Inventory of Adult Temperament Styles (IATS).Validity evidences are reported on 853 middle class adults (43\% female), ages 15 through $54(M=26.5, S D=8.6)$, who were studying at universities or working in Sao Paulo state (Brazil). The degree items are consistent with the four temperament styles was examined through item response theory and confirmatory factor analysis. Results confirm the proposed theoretical structure. Invariance testing suggests that scores reflecting temperament styles have similar meanings for men and women. Implications as well as future directions for research are discussed. Keywords: Assessment, type, styles, temperament, personality.
\end{abstract}

\begin{abstract}
Resumo
O temperamento compreende estilos e traços relativamente estáveis que representam tendências para agir e reagir de formas previsíveis frente aos acontecimentos, pessoas ou estímulos. O temperamento pode ser definido por quatro estilos bipolares: extroversão-introversão, prático-imaginativo, pensamento-sentimento, organizado-flexível. Estes quatro estilos compuseram a estrutura teórica do Inventory of Adult Temperament Styles (IATS). As evidências de validade do IATS foram investigadas em uma amostra de 853 adultos (43\% mulheres), idades entre 25-54 ( $M=26, D P=8,6)$, estudando ou trabalhando no estado de São Paulo. A adequação dos itens em relação aos quatro estilos de temperamento foi examinada através da teoria de resposta ao item e da análise fatorial confirmatória. Os resultados confirmaram a estrutura teórica proposta. O teste da invariância indicou que os estilos de temperamento observados possuem significados semelhantes para homens e mulheres. Implicações e sugestões para futuras pesquisas são discutidas.

Palavras-chave: Avaliação, tipo, estilos, temperamento, personalidade.
\end{abstract}

The discipline of psychology and its clinical practices display an abiding interest in identifying, assessing, and describing temperament qualities that may have a pervasive and important role in shaping development, achieving mental health, and guiding life pursuits (Costa \& McCrae, 2001; Joyce, 2010; McCaulley, 2000; Strelau \& Zawadzki, 2011). The importance attached to temperament is heightened, in part, by knowledge that temperament may provide important psychological insights on protective and risk factor - especially in children (Bayly \& Gartstein, 2013; Klein \& Linhares, 2010; Mangelsdorf, McHale, Dieners, Goldstein, \& Lehn,

\footnotetext{
" Mailing address: Centro de Ciências da Vida, Pontifícia Universidade Católica de Campinas, Curso Pós-Graduação em Psicologia, Campus II, Av. John Boyde Dunlop, Jardim Ipaussurama, Centro, Campinas, SP, Brasil 13060904. E-mail: wechsler@1exxa.com.br
}

2000; Mian, Wainwright, Briggs-Gowan, \& Carter, 2011). Knowledge of temperament also increases our sensitivity to possible ages and cultural differences (Lara, Bisol, et al., 2012; Lima, Lemos, \& Gerra, 2010; Quintana \& Muñoz, 2010). The trait of temperament seemingly is somewhat stable over time for adolescents and adults (Bould, Joison, Sterne, \& Araya, 2013; Canals, Hernandez-Martínez, \& Fernandez-Ballart, 2011).

Contemporary research generally characterizes temperament as stylistic and relatively stable traits that subsume intrinsic (i.e., biological) tendencies to act and react in somewhat predictable ways to people and events (Casalin, Luyten, Vliegens, \& Meurs, 2012; Rothbart \& Hwang, 2002; Worobey, 2001). Although the terms temperament and personality at times are used synonymously, differences exist in their origins, emergence, and robustness. In contrast to personality, the earlier emergence of temperament (Martin, García, Sanz, Arias, \& Matamala, 
2009; Thomas \& Chess, 1977, 1989; Walters, 2011) is attributable to its strongly biological origin. Moreover, while personality may include sixteen or more qualities including motivation and values (Goldsmith et al., 1987), temperament generally is characterized by fewer qualities - often four bipolar qualities.

A model of temperament types proposed by Jung (1943/1953, 1921/1971) and modified and applied by Myers and Briggs in their Myers-Briggs Type Indicator (MBTI; Myers \& Myers, 1980) has been used to examine adults' temperament qualities on four bipolar styles: extroversion-introversion, sensing-intuition, thinkingfeeling, and judging-perception (McCaulley, 2000; Myers,
McCaulley, Quenk, \& Hammer, 1998). The MBTI has been administered in many countries to identify behavioral styles, occupational interests and choices (Atay, 2012; Chauvin, Müller, Godfrey, \& Thomas, 2010; Francis, 2006; Jarlstrom \& Valkealahti, 2010; Kennedy \& Kennedy, 2004; Kummerow \& Maguire, 2010). This model, in slightly revised form, is used internationally to assess children's temperament (Oakland, Glutting, \& Horton, 1996), and its four factor structure has been confirmed in various studies (Benson, Oakland, \& Shermis, 2009; Oakland, Stafford, Horton, \& Glutting, 2001; Rowinski, Cieciuch, \& Oakland, 2013). Table 1 summarizes important temperamental styles in light of this model.

Table 1

Descriptions of Temperament Qualities

Extroversion-Introversion

This dimension describes individuals' orientations to the outer world of people and events around them. Those with extroverted preferences generally are energized by contact with people, while those with introverted preferences generally derive energy from their inner world of thoughts.

Those with extroverted styles generally

Those with introverted styles generally

learn by talking/

learn by reflecting and writing

enjoy large groups

prefer small groups or solitude

have many interests \& friends

have a few interests and close friends

Practical-Imaginative

This dimension describes individuals' orientations to ideas and experience. Those with practical preferences generally attend to facts and objects, while those with imaginative preferences generally view the world in terms of possibilities and insights.

Those with practical styles generally

Those with imaginative styles generally

are realistic/pragmatic

are insightful/visionary/theory oriented

enjoy sequential learning

learn by insight/intuitive leaps

notice details

notice themes/generalizations

Thinking-Feeling

This dimension describes individuals' orientations for making decisions. Those with thinking preferences generally use objective standards to make decisions and strive for fairness, while those with feeling preferences generally use personal standards to make decisions and strive for harmony.

Those with thinking styles generally

Those with feeling styles generally

are analytical/quizzical

are trusting/sympathetic/seek harmony

value logic over sentiment

value sentiment over logic

display brief/businesslike interactions

tactful/friendly interactions

Organized-Flexible

This dimension describes individuals' orientations as to when they make decisions. Those with organized preference styles generally prefer to finalize decisions and have issues settled as soon as possible while those with flexible preference styles generally prefer to delay decisions and keep their options open.

Those with organized styles generally

want to plan/schedule

persist, are dependable

keep personal space neat

enjoy predictable/structure
Those with flexible styles generally

are flexible in commitments

seek opportunity for play

tolerate disorder of possessions

enjoy surprise/adaptive to change 
Gender differences are found principally on thinking and feeling styles. These differences seemingly are universal (Boo \& Kolk, 2006; Hammer \& Mitchell, 1996) and help explain many male-female differences. For example, men generally prefer thinking styles while women generally prefer feeling styles. In contrast to men, women generally display higher personal sensitivity as well as a lower need for activity and intensity pleasure (ElseQuest, Hyde, Goldsmith, \& Van Hulle, 2006; Francis, 2006). Western societies generally value autonomy in men and relatedness and attachment in women (Luyten \& Blatt, 2013; Wechsler, 2009). Gender differences on thinking-feeling were evident in most of the 21 countries in which children's temperament data have been studied (Callueng \& Oakland, 2014; Joyce, 2010).

Brazilian scholarship on temperament focuses mainly on maternal childrearing (Malhado \& Alvarenga, 2012; Melchiori, Alves, Souza, \& Bugliani, 2007) or pathological characteristics related to temperament (Fuscaldo, Bisol, \& Lara, 2013; Lara, Ottoni, Brusntein, Frozi, \& Bisol, 2012; Mochcovitch, Nardi, \& Cardoso, 2012; Tavares \& Gentil, 2007). However, in Brazil, most temperament tests still lack sufficient validity evidences and norms to be used with confidence (Guzzo, Riello, \& Primi, 1996; Ito, Gobita, \& Guzzo, 2007; Klein, Putnam, \& Linhares, 2009). For example, data from the Questionnaire for Types Assessment (QUATI; Zacharias, 2003), designed to assess three types of temperament (extroversion-introversion, sensation-intuition, and thinking-feeling), display adequate test-retest reliability as well as concurrent validity evidence. However, the QUATI's factor structure has been questioned, given evidence that the test measures nine rather than three factors and that evidence for the sensation-intuition factor is limited (Moraes \& Primi, 2002). Thus, additional evidence as to the factor structure of temperament tests in Brazil is needed. The purpose of this research was to examine the factor structure of the Inventory of Adult Temperament Styles (IATS). This research also investigates possible gender differences in temperament styles among Brazilians, given pervasive international research showing such differences.

\section{Method}

\section{Participants}

Data were collected on 853 middle class adults (43\% female), ages 15 through $54(M=26.5, S D=8.6)$, who attended universities or worked in various professions in Brazil's state of Sao Paulo. These persons were contacted by their professors or employees and invited to participate in the study.

\section{Instrument}

The theoretical foundation for the Inventory of Adult Temperament Styles (IATS) is based on prevailing temperament models (e.g. Myers et al., 1998; Oakland et al., 1996), that utilize four bipolar temperament styles: extroversion-introversion, practical-imaginative, thinkingfeeling, and organized-flexible. One hundred items forcedchoice items were created to be consistent with this model. Each item has two opposing options.

\section{Procedure}

Approval by the Brazilian Ethics Research Committee was secured (N.277/07). The IATS was group administered to college and professionals at university or work settings. Raw scores were used for data analysis in order to preserve statistical properties of the observed score distribution. The fit of items with their respective temperament styles was evaluated using the two parameter logistic model from item response theory (IRT). This model was utilized because the magnitude of relationships between items and temperament styles was presumed to vary. A three parameter model was not utilized because the guessing parameter is not of interest when examining dichotomous temperament items. Separate analyses were performed for the extroversion-introversion, practical-imaginative, thinking-feeling, and organized-flexible styles, to verify the proposed four-factor model.

IRT analyses were conducted using the Xcalibre 4.1 computer program (Guyer \& Thompson, 2012) following the maximum likelihood estimation approach. Items were removed if they demonstrated either negative point bi-serial correlations or poor fit with their respective temperament dimension. Items were considered to display acceptable fit if the $z$ residual fit statistic did not exceed the two-tailed critical alpha value of 01 .

The next stage of data analysis involved the use of item parceling methods. Item parceling involves combining items into groups (Gorsuch, 1983). Item parceling was warranted because the variance of individual items was restricted due to their dichotomous format. Moreover, parceling yields aggregated scores that have greater variability than scores obtained from individual items. Three parcels of approximately equal size were constructed for each dimension of the four bipolar temperament styles, as the use of three parcels per dimension produces a justidentified construct that ". . . has only one unique solution that optimally captures the relations among the items" (Little, Cunningham, Shahar, \& Widaman, 2002, p. 162).

Confirmatory factor analysis (CFA) was used to exam correspondence of the remaining 79 items to a four factor structure, with each factor representing one bipolar temperament style. The factor loadings of parcels on their respective temperament styles were freely estimated. Additionally, measurement errors and correlations among the styles were freely estimated. CFA was used to test the extent to which the hypothesized model presented in Figure 1 fits data obtained from the total sample as well as data from disaggregated male and female samples. Next, parcel invariance was examined across men and women to determine if the data demonstrate configural invariance (i.e., whether the measured variables define the same factors and have the same pattern of loadings across males and 


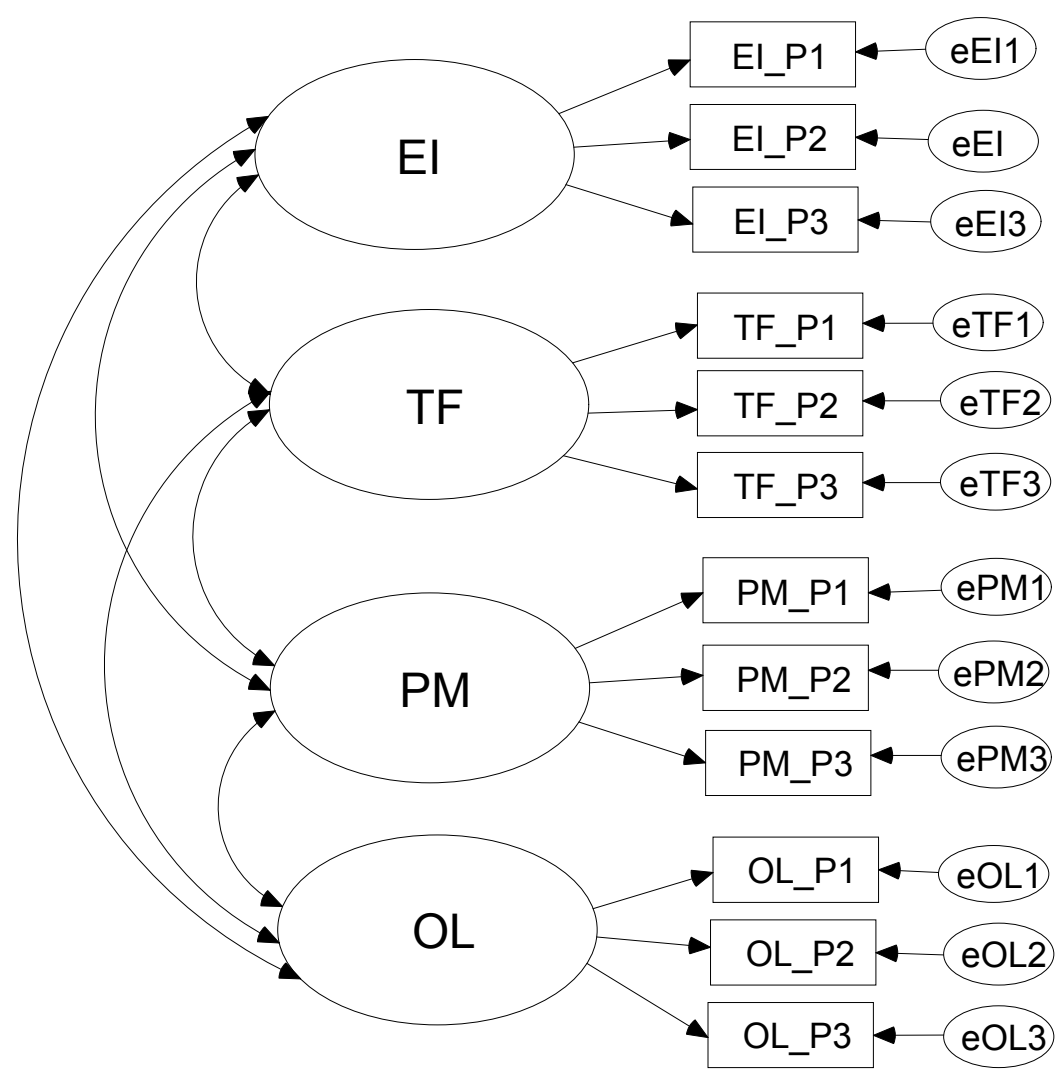

Figure 1. Measurement model for the Inventory of Adult Temperament Styles.

women) and metric invariance (i.e., whether the magnitude of observed variables' factor loadings are invariant across men and women).

CFA analyses were performed using Amos 16.0 (Arbuckle, 2007) computer software following the method of maximum-likelihood estimation. Multiple fit indices were used to judge model fit. Multiple index presentation strategies help control the error rate for accepting misspecified models (Hu \& Bentler, 1999). The indices utilized in this study include the comparative fit index (CFI), root mean square error of approximation (RMSEA), standardized root mean square residual (SRMR), and change in chi-square value $\left(\Delta \chi^{2}\right)$. The successive models used to test invariance are nested. Thus, a likelihood ratio test $\left(\Delta \chi^{2}\right)$ was used to determine if adding theoretically substantive constraints result in a large and statistically significant drop in $\chi^{2}$ values (Keith, 2005). Additionally, change in CFI and RMSEA values was examined when evaluating invariance. CFI changes of .01 or less and RMSEA changes of .015 or less were used as criteria for establishing invariance.

\section{Results}

Seventy-nine items were acceptable based on fit with the two parameter logistic model from IRT. Twenty-one items were removed because they demonstrated either negative point bi-serial correlations or poor fit with their respective temperament dimension. Twenty-one items assess extroversion-introversion, 19 assess organized- flexible, 18 assess practical-imaginative, and 21 assess thinking-feeling styles.

All scales (i.e., dimensions) had reasonable $a$ parameter estimates. The typical range for estimates is .30 to 1.50 (Guyer \& Thompson, 2012), and estimates for all retained items either fell within or approximated this range. The range and average of $a$ parameter estimates within each dimension are as follows: .22 to 1.16 with a mean of .58 for extroversion-introversion, .32 to 1.16 with a mean of .64 for organized-flexible, .17 to 1.16 with a mean of .53 for practical-imaginative, and .17 to 1.16 with a mean of .53 for thinking-feeling. Results suggest that items within each dimension have discriminative value when assessing individual differences in temperament styles.

All estimates for the $b$ parameter fall within the typical range of -3 to 3 (Guyer $\&$ Thompson). The $b$ parameter is related to item means and reflects the probability of endorsing a response indicative of a particular temperament style. The range and average of $b$ parameter estimates within each dimension are as follows: -2.45 to 1.42 with a mean of -.80 for extroversion-introversion, -1.71 to 2.52 with a mean of -.43 for organized-flexible, -2.14 to 2.52 with a mean of -.17 for practical-imaginative, and -2.87 to 2.21 with a mean of -.24 for thinking-feeling.

Individual items were selected from item pools for each style and assigned randomly to one of three parcels in to reduce unwanted sources of variance and parameter bias when examining model fit (Little et al., 2002). Parcel data are reported in Table 2. Global fit statistics, which 
reflect the fit of the CFA model presented in Figure 1 to the observed data, are presented in Table 3. Model parameter estimates, including standardized regression weights for parcels and correlations among latent temperament styles, are presented in Tables 2 and 4, respectively. Although fit statistics generally indicate reasonable fit between the hypothesized model and the observed data, the CFI value observed for women falls below .95. All parcels load moderately well on their respective factors. Correlations among latent factors generally are small. However, organized-flexible styles correlate moderately with practical-imaginative and thinking-feeling styles. Moreover, among women, extroversion-introversion and practical-imaginative styles correlate moderately

Table 2

Descriptions of Parcels and Loadings of Parcels on Associated Styles

\begin{tabular}{lccccc}
\hline \multicolumn{1}{c}{ Dimension } & Parcel & Items & Total group & Women & Males \\
\hline Extroverted-Introverted & 1 & $13,17,33,37,45,61,77$ & .742 & .722 & .760 \\
& 2 & $5,9,29,41,49,57,65$ & .659 & .674 & .648 \\
Practical-Imaginative & 3 & $21,25,53,69,73,81,85$ & .610 & .691 & .537 \\
& 1 & $18,26,34,54,74,82$ & .576 & .627 & .549 \\
Organized-Flexible & 2 & $2,14,38,46,50,86$ & .607 & .576 & .607 \\
& 3 & $6,30,66,70,78,89$ & .584 & .542 & .599 \\
Thinking-Feeling & 1 & $4,16,36,44,48,80,99$ & .753 & .792 & .714 \\
& 2 & $8,56,72,88,91,95$ & .571 & .597 & .549 \\
& 3 & $24,60,64,68,76,93$ & .746 & .732 & .761 \\
& 1 & $7,19,43,55,59,63,90$ & .567 & .478 & .611 \\
& 2 & $27,67,79,83,87,96,100$ & .573 & .587 & .578 \\
& 3 & $15,23,31,35,47,51,75$ & .571 & .542 & .570 \\
\hline
\end{tabular}

Table 3

Global Model Fit for Female, Male, and Total Samples

\begin{tabular}{lccccc}
\hline & \multicolumn{1}{c}{$\chi^{2}(d f)$} & $p$ & CFI & RMSEA & SRMR \\
\hline Women & $105.898(48)$ & $<.001$ & .930 & $.057(.042-.072)$ & .056 \\
Males & $88.521(48)$ & $<.001$ & .956 & $.042(.028-.055)$ & .048 \\
Total sample & $140.779(48)$ & $<.001$ & .947 & $.048(.039-.057)$ & .046 \\
\hline
\end{tabular}

Note. CFI = Comparative Fit Index, RMSEA = Root Mean Square Error of Approximation, SRMR = Standardized Root Mean Square Residual.

Table 4

Correlations among Latent Styles of Temperament

\begin{tabular}{lccc}
\hline Correlations & Women & Males & Total Sample \\
\hline EI and OL & .215 & -.171 & -.024 \\
EI and PM & .392 & -.101 & .134 \\
EI and TF & -.017 & -.196 & -.126 \\
OL and PM & .487 & .377 & .411 \\
OL and TF & .322 & .276 & .305 \\
PM and TF & .155 & -.050 & .002 \\
\hline
\end{tabular}

Note. $\mathrm{EI}=$ extroversion-introversion; $\mathrm{TF}=$ thinking-feeling; $\mathrm{OL}=$ organized-flexible; $\mathrm{PM}=$ practical-imaginative. 
Wechsler, S. M., Benson, N., Oakland, T. \& Lourençoni, M. A. (2014). Factor Structure of the Inventory of Adult Temperament Styles.

Results from tests of measurement invariance are presented in Table 5. Configural and metric invariance are supported for men and women. An invariant struc- tural configuration indicates that items measure the same constructs in both groups. Metric invariance indicates that factors are calibrated in a similar way and thus have similar meanings for men and women (Steinmetz, 2011).

Table 5

Summary of Results for Measurement Invariance Testing Across Gender Groups

\begin{tabular}{cccccccc}
\hline Step & Constraints & $\chi^{2}(d f)$ & $\Delta \chi^{2}$ & $\Delta d f$ & $p$ & CFI & RMSEA \\
\hline $\begin{array}{c}\text { Configuration only } \\
\text { Measurement weights }+ \\
\text { previous }\end{array}$ & $194.432(96)$ & - & - & - & .944 & $.035(.028-.042)$ \\
& $204.544(104)$ & 10.111 & 8 & .257 & .942 & $.034(.027-.040)$ \\
\hline
\end{tabular}

Note. $\mathrm{AIC}=$ Akaike Information Criterion, $\mathrm{CFI}=$ Comparative Fit Index, RMSEA $=$ Root Mean Square Error of Approximation, $\mathrm{SRMR}=$ Standardized Root mean Square Residual.

\section{Discussion}

Assessment of temperament styles provides important information that can be used to better understand people's predisposition to display certain behaviors and help them to achieve life pursuits. Although scholarly literature on temperament exists in Brazil (Guzzo et al., 1996; Klein et al., 2009), its focus largely has been on child rearing practices (Malhado \& Alvarenga, 2012; Melchiori et al., 2007) and use in clinical setting (Lara, Ottoni, et al., 2012, Mochcovitch et al., 2012). Its limited focus precludes the use of temperament assessment for other purposes such as vocational guidance or personnel assessment. Therefore, this research examined the factor structure of the Inventory of Adult Temperament Styles (IATS) together with possible gender differences on thinking-feeling styles among Brazilians.

Results indicate that the fit between the hypothesized model and the observed data generally is adequate, thus confirming a four factor structure of temperament (extroversion-introversion, practical-imaginative, thinking-feeling, and organized-flexible styles). These findings are congruent with international research with this temperament model as reported by others (e.g., Benson, et al., 2009; Callueng \& Oakland, 2014; Myers \& Myers, 1980; Rowinski et al., 2013) and add evidence as to the validity of the IATS's internal structure.

Small to moderate correlations among some temperament styles were found, with organized-flexible and practical-imaginative styles sharing approximately $17 \%$ common variance. Thus, the temperament qualities measured by these two styles are not unique to them and instead share a more general temperament quality - albeit modestly. Other attempts to develop items that measure only a pure, single and unique temperament style have not been successful (Benson et al., 2009; Myers \& Myers, 1980; Oakland et al., 1996).

This research also examined investigated possible gender differences in temperament styles among Bra- zilians, given pervasive international research showing such differences. Invariance testing suggests that scores reflecting temperament styles have similar meanings for men and women. In general, international research suggests that men are more likely to prefer a thinking style while women are more likely to prefer a feeling style (Callueng \& Oakland, 2014; Francis, 2006; Joyce, 2010; Myers et al., 1998). This finding is consistent with previous Brazilian data related to gender and creative styles (Wechsler, 2009), thus confirming that, in western societies, women display a greater need for attachment (Else-Quest et al., 2006). Thus, differences in women's temperament styles might be reflecting their clear tendency to look for harmony, to value sentiments over logic and their tendency to be more sympathetic and friendly in their interactions than men.

\section{Limitations and Directions for Future Research}

Although results confirm the IATS' theoretical structure, evidence regarding the reliability of scores derived from the IATS is needed. Moreover, external validity evidence regarding the relations of IATS scores with other measures of temperament, as well as relations with other constructs, is necessary. Evidence regarding the utility of IATS scores for applied purposes such as career counseling, organizational development, or treatment planning would be beneficial so that test users can make informed decisions regarding the consequences of test use. Finally, evidence regarding differences on the frequency of temperament styles in the Brazilian population is needed given the present lack of appropriate tests for measuring Brazilian's temperament styles.

\section{References}

Arbuckle, J. L. (2007). Amos 16.0 [Computer software]. Chicago, IL: Smallwaters.

Atay, S. (2012). The standardization of Myers-Briggs Type Indicator into Turkish: An application on students. Journal of Instructional Psychology, 39(2), 74. 
Bayly, B., \& Gartstein, M. (2013). Mother's and father's reports on their child's temperament: Does gender matter? Infant Behavior and Development, 36(1), 171-175. doi:10.1016/j. infbeh.2012.10.008

Benson, N., Oakland, T., \& Shermis, N. (2009). Crossnational invariance of children's temperament. Journal of Psychoeducational Assessment, 27(1), 3-16. doi:10.1177/0734282908318563

Boo, G. M., \& Kolk, A. (2006). Ethnic and gender differences in temperament and the relationship between temperament and depressive and aggressive mood. Personality and Individual Differences, 43, 1756-1766. doi:10.1016/j.paid.2007.05.012

Bould, H., Joinson, C., Sterne, J., \& Araya, R. (2013). The Emotionality Activity Sociability Temperament Survey: Factor analysis and temporal stability in a longitudinal cohort. Personality and Individual Differences, 54, 628-633. doi:10.1016/j.paid.2012.11.010

Callueng, C., \& Oakland, T. (2014). If you don't know the child's temperament you don't know the child. Estudos de Psicologia (Campinas), 31, 3-13. doi:10.1590/0103166X2014000100001

Canals, J., Hernandez-Martínez, C., \& Fernandez-Ballart, J. D. (2011). Relationships between early behavioural characteristics and temperament at 6 years. Infant Behavior and Development, 34, 152-160. doi:10.1016/j.infbeh.2010.11.003

Casalin, S., Luyten, P., Vliegens, N., \& Meurs, P. (2012). The structure and stability of temperament from infancy to toddlerhood: A one-year prospective study. Infant Behavior \& Development, 35, 94-108. doi:10.1016/j.infbeh.2011.08.004

Chauvin, I., Müller, M. J., Godfrey, L. L., \& Thomas, D. (2010). Relationship between Holland's vocational typology and Myers-Briggs' types: Implications for career counselors. Psychology Journal, 7(2), 61-66.

Costa, P. T., Jr., \& McCrae, R. R. (2001). A theoretical context for adult temperament. In T. D. Wachs \& G. A. Kohnstamm (Eds.), Temperament in context (pp. 1-21): Mahwah, NJ: Lawrence Erlbaum.

Else-Quest, N. M., Hyde, J. S., Goldsmith, H. H., \& Van Hulle, C. A. (2006). Gender differences in temperament: A meta-analysis. Psychological Bulletin, 132, 33-72. doi:10.1037/00332909.132.1.33

Francis, L. (2006). Psychological types of female trainee primary school teachers in Wales. Journal of Psychological Type, 2, 9-19.

Fuscaldo, L. V., Bisol, L., \& Lara, D. R. (2013). How emotional traits and affective temperament relate to cocaine experimentation abuse and dependence in a large simple. Addictive Behaviors, 38, 1859-1864. doi:10.1016/j.addbeh.2012.11.009

Goldsmith, H. H., Buss, A. H., Plomin, R., Rothbart, M. K., Thomas, A., Chess, S., ...McCall, R. B. (1987). Roundtable: What is temperament? Four approaches. Child Development, 58, 505-529. doi:10.1111/1467-8624.ep7253747

Gorsuch, R. L. (1983). Factor analysis. Hillsdale, NJ: Lawrence Erlbaum.

Guyer, R., \& Thompson, N. A. (2012). User's manual for Xcalibre item response theory calibration software, version 4.1.7. St. Paul, MN: Assessment Systems Corporation

Guzzo, R. S. L., Riello, I. C., \& Primi, R. (1996). Pavlovian Temperament Survey- PTS: Análise de ítens e teste de realidade. Psicologia Escolar e Educacional, 1, 53-59. doi:10.1590/ S1413-85572003000200008

Hammer, A. L., \& Mitchell, W. D. (1996). The distribution of MBTI types in the US by gender and ethnic group. Journal of Psychological Type, 37, 2-15.
Hu, L., \& Bentler, P. M. (1999). Cutoff criteria for fit indexes in covariance structural analysis: Conventional criteria versus new alternatives. Structural Equation Modeling, 6, 1-55. doi:10.1080/10705519909540118

Ito, P. C., Gobitta, M., \& Guzzo, R. S. L. (2007). Temperamento, neuroticismo e auto-estima: Um estudo preliminar. Estudos de Psicologia (Campinas), 24, 143-153. doi:10.1590/S0103166X2007000200001

Jarlstrom, M., \& Valkealahti, K. (2010). Person-job fit related to psychological type of finish business students and managers. Journal of Psychological Type, 4, 41-52.

Joyce, D. (2010). Essentials of temperament assessment. New York: Wiley.

Jung, C. G. (1953). Two essays on analytical psychology (R. F. C. Hull, Trans.). New York: Pantheon Books. (Original work published 1943)

Jung, C. G. (1971). Psychological types (R. F. C. Hull, Revision \& H. G. Baynes, Trans.). Princeton, NJ: Princeton University Press. (Original work published 1921)

Keith, T. Z. (2005). Using confirmatory factor analysis to aid in understanding the constructs measured by intelligence tests. In D. P. Flanagan \& P. L. Harrison (Eds.), Contemporary intellectual assessment: Theories, tests, and issues $\left(2^{\text {nd }}\right.$ ed., pp. 581-614). New York: Guilford Press.

Kennedy, R. B., \& Kennedy, D. A. (2004). Using the MyersBriggs type indicator in career counseling. Journal of Employment Counseling, 41, 38-44.

Klein, V. C., \& Linhares, M. B. M. (2010). Temperamento e desenvolvimento da criança: Revisão sistemática da literatura. Psicologia em Estudo, 15(4), 821-829.

Klein, V. C., Putnam, S. P., \& Linhares, M. B. M. (2009). Assessment of temperament in children: Translations of instruments to Portuguese (Brazil) language. Interamerican Journal of Psychology, 43(3), 552-555.

Kummerow, J. M., \& Maguire, M. J. (2010). Using the MyersBriggs indicator framework with an Adlerian perspective to increase collaborative problem solving in an organization. The Journal of Individual Psychology, 66(2), 189-199.

Lara, D. R., Bisol, L. W., Brunstein, M. G., Reppold, C. T., Carvalho, H. W., \& Ottoni, G. (2012). The Affective and Emotional Composite Temperament (AFECT) model and scale: A system-based integrative approach. Journal of Affective Disorders, 140(1), 14-37. doi:10.1016/j.jad.2011.08.036

Lara, D. R., Ottoni, G. L., Brusntein, M. G., Frozi, H. W. C., \& Bisol, L. W. (2012). Development and validity of the Brazilian Internet Study on Temperament and Psychopathology (BRAINSTEP). Journal of Affective Disorders, 141(2-3), 390-398. doi:10.1016/j.jad.2012.03.011

Lima, L., Lemos, M. S., \& Gerra, M. P. (2010). Adaptação do Inventário de Temperamento para Crianças em Idade Escolar School Age Temperament Inventory - SATIDE de McLowry para uma população portuguesa. Psicologia, Saúde \& Doença, 11(1), 55-70.

Little, T. D., Cunningham, W. A., Shahar, G., \& Widaman, K. F. (2002). To parcel or not to parcel: Exploring the question, weighing the merits. Structural Equation Modeling, 9(2), 151-173. doi:10.1207/S15328007SEM0902_1

Luyten, P., \& Blatt, S. (2013). Interpersonal relatedness and self-definition in normal and disruptive personality development: Retrospect and prospect. American Psychologist, 68(3), 172-183. doi:10.1037/a0032243

Malhado, S. C. B., \& Alvarenga, P. (2012). Relações entre o temperamento infantil aos oito meses e as práticas educativas maternas aos 18 meses de vida. Estudos de Psicologia 
Wechsler, S. M., Benson, N., Oakland, T. \& Lourençoni, M. A. (2014). Factor Structure of the Inventory of Adult Temperament Styles.

(Campinas), 29(Supl. 1), 787-797. doi:10.1590/S0103166X2012000500015

Mangelsdorf, S. C., McHale, J. L., Dieners, M., Goldstein, L. H., \& Lehn, L. (2000). Infant attachment: Contributions of infant temperament and maternal characteristics. Infant Behavior \& Development 23(2), 175-196. doi:10.1016/S01636383(01)00035-2

Martin, J. M. R., García, M. J. S., Sanz, P. C., Arias, T. V., \& Matamala, B. I. (2009). El temperamento infantil en el ámbito de la prevención primaria. Relación con el cociente de desarrollo y su modificablidad. Clínica y Salud, 20(1), 67-78.

McCaulley, M. H. (2000). Myers-Briggs Type Indicator: A bridge between counseling \& consulting. Consulting Psychology Journal: Practice and Research, 52(2), 117-132. doi:10.1037/1061-4087.52.2.117

Melchiori, L., Alves, Z. M. M. B., Souza, D. C., \& Bugliani, M. A. P. (2007). Família e creche: Crenças a respeito de temperamento e desempenho de bebês. Psicologia, Teoria e Pesquisa, 23(3), 245-252. doi:doi.org/10.1590/S141335552011005000015

Mian, N. D., Wainwright, L., Briggs-Gowan, M. J., \& Carter, A. S. (2011). An ecological risk model for early childhood anxiety: The importance of early child symptoms and temperament. Journal of Abnormal and Child Psychology, 39(4), 501-512. doi:10.1007/s10802-010-9476-0

Mochcovitch, M. D., Nardi, A. E., \& Cardoso, A. (2012). Temperament and character dimension and their relationship to major depression and panic disorder. Revista Brasileira de Psiquiatria, 34(3), 342-351. doi:10.1016/j.rbp.2012.03.002

Moraes, I. F., \& Primi, R. (2002). Escala de avaliação de tipos psicológicos: Validade e precisão. Psico-USF, 7(1), 25-34.

Myers, I. B., \& Myers, P. B. (1980). Gifts differing. Palo Alto, CA: Consulting Psychologists Press.

Myers, I. B., McCaulley, M. H., Quenk, N. L., \& Hammer, A. L. (1998). MBTI: Manual: A guide to the development and use of the Myers-Briggs type indicator. Palo Alto, CA: Consulting Psychologists Press.

Oakland, T., Glutting, J. J., \& Horton, C. B. (1996). Student Styles Questionnaire. San Antonio, TX: Psychological Corporation.

Oakland, T., Stafford, M., Horton, C., \& Glutting, J. (2001). Temperament and vocational preferences: Age, gender, and racial-ethnic comparisons using the Student Styles Questionnaire. Journal of Career Assessment, 9, 297-314. doi:10.1177/106907270100900306

Quintana, T., \& Muñoz, G. (2010). Validación y adaptación del Cuestionario de Temperamento y Caráter, JCTI de R. Cloninger, versión niños y padres, a escolares chilenos entre 8 y 13 años de edad. Terapia Psicológica, 28(1), 37-43.

Rothbart, M. K., \& Hwang, J. (2002). Measuring infant temperament. Infant Behavior \& Development, 25, 113-116. doi:10.1016/S0163-6383(02)00109-1

Rowinski, T., Cieciuch, J., \& Oakland, T. (2013). The factorial structure of four temperament styles and measuring invariance across gender and age groups. Journal of Psychoeducational Assessment, 32(1), 77-82 doi:10.1177/0734282913487045

Steinmetz, H. (2011). Analyzing observed composite differences across groups: Is partial measurement invariance enough? Methodology: European Journal of Research Methods for the Behavioral and Social Sciences, 1-12. Advance online publication. doi:10.1027/1614-2241/a000049

Strelau, J., \& Zawadzki, B. (2011). Fearfulness and anxiety in research on temperament: Temperamental traits are related to anxiety disorders. Personality and Individual Differences, 50(7), 907-915. doi:10.1016/j.paid.2010.07.008
Tavares, H., \& Gentil, V. (2007). Psychological gambling an obsessive-compulsive disorders: Towards a spectrum of disorders of volition. Revista Brasileira de Psiquiatria, 29(2), 107-117.

Thomas, A., \& Chess, S. (1977). Temperament and development. New York: Brunner.

Thomas, A., \& Chess, S. (1989). Temperament and personality. In G. A. Kohnstamm, J. E. Bates, \& M. K. Rothbart (Eds.), Temperament in childhood (pp. 249-261). New York: Wiley.

Walters, G. D. (2011). Childhood temperament: Dimensions or types? Personality and Individual Differences, 50(8), 11681173. doi:10.1016/j.paid.2011.02.014

Wechsler, S. M. (2009). Age and gender impact on thinking and creating styles. European Journal of Education and Psychology, 2(1), 37-48.

Worobey, J. (2001). Associations between temperament and love attitudes in a college sample. Personality and Individual Differences, 31(3), 461-469. doi:10.1016/S01918869(00)00154-9

Zacharias, J. J. M. (2003). QUATI- Questionário de Avaliação Tipológica-Versão II (5. ed.). São Paulo, SP: Vetor. 